UDC 32.061.[EU:342.25]:32-047.74(477)

\author{
Vitkova V. S. \\ Ph. D., Associate Professor \\ Constitutional Law Department \\ National University «Odesa Law Academy» \\ Fontanska doroga str., 23, Odesa, 65009, Ukraine \\ Tel.: (38048)719-88-15 \\ E-mail: valentina vitkova@i.ua \\ ORCID iD: http://orcid.org/0000-0002-5819-8107 \\ DOI: http://dx.doi.org/10.18524/2304-1439.2019.32.173846

\section{EUROPEAN REGIONAL POLICY: GENERAL CHARACTERISTICS, CHALLENGES AND PROSPECTS FOR UKRAINE}

The work is devoted to the study of the main features of European regional policy. EU regional policy is the quintessence of experience for countries facing the need to address similar legal issues. The need to bring the national system of public authority and public administration closer to European standards, to develop an effective model of regional governance, etc., calls for an in-depth study of European regional policy. To date, Ukraine is not a member state of the European Union, although the constitutional consolidation of Ukraine's European course gives every reason to believe that the orientation towards positive European experience and the shortcomings that EU member states have already encountered in implementing regional policy are not only extremely relevant, but also vital to the Ukrainian state at the present stage of constitutional change. In the current context, it is impossible to formulate mechanisms of state regional policy, without taking into account the current trends used by the international community. Since 2014, regional policy in Ukraine has begun to take on a European Union regional policy. The existing legislation regulates the fullest extent of public relations in the field of regional policy during the independence of Ukraine and meets European standards. State regional policy faces the challenge of providing each region with the full potential to maximize its internal potential while maintaining national interests. The current stage of the state is characterized by the exercise of systematic influence on the improvement of regional policy. Although many problems (disproportionate development of the regions, the dynamics of transformation processes in the economic development of the country, etc.) still require their solution, the correctness and productivity of the course chosen by the Ukrainian state is demonstrated today.

Key words: European regional policy, European Union, regions, regional development, regional governance.

Basement of the Study. It is well-known that effective regional policy is a pledge of development and stability of the state, first of all, economic and political. According to the Cabinet of Ministers of Ukraine, in 2014, only six regions in Ukraine were self-sufficient, which caused significant regional imbalances, and, consequently, the quality of life and services received by Ukrainians. These challenges required carrying out fundamental reforms in terms 
of public administration, local self-government and territorial organization of power in Ukraine [1]. Today, one of the most important priorities for the Ukrainian state is carrying out the reform of decentralization of power and public administration. The relevance of this trend is evidenced by the adoption in recent years a number of normative legal acts, in particular approval by the Decree of the President of Ukraine dated January 12, 2015, № 5/2015 Sustainable Development Strategy «Ukraine 2020»; adoption of the Law of Ukraine «On the Principles of State Regional Policy» dated February 5, 2015, № 156-VIII; introduction of amendments to the Fundamental Law of Ukraine in 2019 on the strategic course of the state on acquiring full-fledged membership of Ukraine in the European Union and the North Atlantic Treaty Organization, etc. However, the successful implementation of public administration reform and decentralization is impossible without a scientifically and practically substantiated system of regional governance.

In the modern world, the European Union, in spite of significant social and economic disproportions, which are usually increased after the accession of new countries to the EU, introduces and demonstrates the effectiveness of regional development standards. The success of the regional development policy is based on the establishment of EU partnerships, strategic planning and good governance. If these principles are applied, the management of regional development programs can be decentralized. This is the quintessence of the gained experience, which forms the basis for political dialogue with other countries of the world, faced with the need to solve similar by legal nature problems. Indeed, regions of different countries characterize a large number of common problems. Fulfilling the desire to combine existing resources and test practical experience, the European Union has decided to establish partnerships in the form of «memoranda of understanding» with several non-EU countries. One of these countries is also Ukraine. Such partnerships are based, first of all, on the European experience of reducing regional disparities, improving the quality of governance and creating effective, topical strategies. Challenges of the present predetermine the need for global thinking that goes far beyond the boundaries of one country's problems, but also the need to act locally to achieve not only effective but most constant results. The set of challenges faced by the regions of the world are characterized by perceptible territorial characteristics, which necessitate appropriate responses at the local and regional levels. Obviously, the European Union can not alone solve these problems, which is why productive cooperation with non-EU countries is important both for the European Union and, above all, it is in the interests of Ukraine. The abovementioned determines the relevance of the chosen topic of research.

The aim of the research. The purpose of this study is to conduct theoretical analysis of the experience of implementation and realization of European regional policy in order to determine the possibilities of implementation of positive achievements of the EU member states for Ukraine.

Analysis of Researches. Certain aspects of European regional policy are researched by many scientists and practicians. Despite quite significant sci- 
entific advances in this area, the interest of the researchers not only does not subsides, but also, on the contrary, is actualized, which is due, obviously, to the complexity of introducing real changes in the practice of state building and the variability of factors of development of state and public life.

Thus, O. Y. Prokopenko emphasized that such management technology as a system of strategic planning of the region's development is practically not used and emphasized the need for further research to overcome the problem of efficiency of the use of resources in rural communities [2, p. 3]. E. Kh. Topalovanoted the lack of elaboration of theoretical and practical principles for the building up of an effective model of regional governance. The researcher emphasized that in Ukraine, unlike the European Union, the principles of governance at the regional level, which have not yet acquired their constitutional and legislative consolidation, are often identified or replaced by the principles of local self-government [3, p. 15]. R. A. Kolyshko rightly pointed out that the problem of the lack of balanced regional policy occupies a separate place, which caused uneven regional development that is increases every year; the need to overcome the negative effects of uncontrolled regional development entails the need to represent the political, economic and cultural interests of the regions at the central level [4]. Kurylyak M. Yu. emphasized that the entry into force of the Association Agreement between Ukraine on the one hand, and the European Union and its member states, on the other hand, makes an actual the search and development of the adapted for Ukrainian conditions integration forms and methods of cooperation between them in a regional section. One must agree with the assertion of the researcher that in today's world, civilized countries face global threats, the solution of which is impossible without international cohesion, especially regional communities. Partnership on the borders of European countries should ensure the construction of a safe environment, the elimination of crises in the common region, the economic growth of the poorest regions and the management of the root causes of migration [5, p. 60]. S. O. Bila in her research claimed that decentralization is an integral part of the state regional policy in Ukraine. The state and systemic problems of the formation and implementation of regional policy in Ukraine are periodically highlighted in the works of leading Ukrainian scientists. Thus, an issue of the fundamental principles and strategic perspectives for reforming the national regional policy was considered by S. L. Schulz., Ukrainian scientists M. P. Butko, O. D. Khomik, S. M. Pisarenko and others in their works traditionally focused on the need to harmonize the strategic priorities of the state regional policy in Ukraine with the European integration vector of social development; stressed on the formation of the foundations of a new regional policy based on a paradigm that organically combines the principles of subsidiarity and decentralization of territorial organization of power [6, p. 61]. In her turn, V. S. Shtefan came to the conclusion that the EU development envisages the continuous increase of the role of regions, the elimination of the imbalance between the urban settlements of different subordination, the reform of regional policy [7, p. 184]. K. I. Sieriebryak argued that the current preconditions for the development of the information infra- 
structure of economic cooperation of the regions of Ukraine include the directions of the development of regional information policy, but it is emphasized that the key precondition for the development of the information infrastructure of regional economic cooperation is the information security that determines all other attributes of the modern regional information policy [8, p. 23]. A. Melnik, V. Adamik determined the need of the highlighting of important issues and problems of regional policy, which should be taken into account in the development and realization of the strategy of cooperation, while the main areas of such cooperation should be: strategic definition of goals; implementation of the experience of the CEE countries in the development and functioning of Euroregions, primarily Poland with the Federal Republic of Germany, the Czech Republic with the Federal Republic of Germany, Slovenia with Italy; support for integrated infrastructure improvement programs; the need for modernization of regional policy mechanisms - the mechanism of choosing priorities, the mechanism of financing structural changes in the regions, the mechanism of strategizing, the mechanism of reorientation of investments in priority industries, sectors of the economy [9, p. 76]. Accordant is the position of O. Polikarpova, who singled out the importance of using the experience of regional policy of those countries that have undergone a transitional stage of development and became members of the European Union. The experience of countries such as Poland, Slovakia, Czech Republic, Latvia, Lithuania in the field of regional policy shows the high efficiency of the introduction of European models. At the same time, it is expedient to introduce the basic principles of the model of regional policy of the European Union at the basis of the formulation of an effective regional policy of Ukraine: strategic approach, standards, stimulation of the internal development of regions based on the use of local conditions and resources, development of a mechanism for redistribution of financial resources, strengthening of local initiative, motivation of regions for self-development, diversification of spheres of economic activity, overcoming paternalistic expectations [10, p. 107]. T. M. Krasnopolskaya argues that regional policy has existed for many years in all developed countries, and its main task is to equalize spatial disproportions in the level of socio-economic development; within the framework of such a policy of achieving regional goals and mitigating these disproportions placed the state at the forefront. Regional policy is the most effective equalization tool. The attention is drawn to the fact that the experience of Western European countries and regional policy of the European Union are of particular interest to Ukraine, since Western Europe is characterized by greater spatial disproportions than in North America, and the belief in the regulatory powers of the state is traditional here [11, p. 81].

Despite the presence of a certain number of publications, a range of dynamic factors, such as the need to bring the domestic system of public power and public administration closer to European standards, the development of an effective model of regional governance, etc., necessitates an in-depth study of the European regional policy, reflected in the formulated research goal. 
The methodology of the research. The methodological basis of the study advocated by a set of general and special methods that are consistent with the aim of this study: the formal-logical method was used in determining the essential characteristics of the key concepts of the study; the system-analytical method was used for the analysis of international legal acts and other normative documents; the method of comparative analysis was used when investigating the compliance of the existing model of regional governance in Ukraine with European standards; historical method - for conducting research on the historical establishment of the Institute of European Regional Policy; by means of the formal-juridical method were distinguished current problems in the sphere of the introduction of European regional policy; the prognostic method made possible the nomination of assumptions about the possibilities of regional policy in Ukraine; the bibliographic method was used in the study and further elaboration of scientific works devoted to the problems of European regional policy; the method of theoretical generalization - in the study of theoretical foundations of the Institute of European Regional Policy.

In order to fully understand the present state of European regional policy, its origins should be addressed. Despite the fact that in the preamble of the "Treaty Establishing the European Community» (1957) it was about ensuring harmonious economic development, reduction of existing differences between different regions and overcoming the backwardness of regions, which are in the least favorable conditions [12], at the very beginning of the association was taken for granted allegations that integration will automatically lead to the equalization of interregional imbalances, and therefore regional policy measures were not considered to be priority.

The start of the European integration process and its further expansion began with the presence of significant disparities between the regions and the EU member states. The mechanism of realization of regional policy in the European Union was formed in stages: the first phase covered the 1970s-1980s, when such a policy was based on a system of common funding of the regional policy of the member states. The first instrument for implementing such a policy was the European Regional Development Fund, created in 1975 after joining the Community by the United Kingdom and Denmark [13, p. 102].

At the second stage there was a final transition to an independent regional policy at the EU level, budget allocations to the Fund increased considerably. In 1989, the medium-term programming of regional development was launched (two program periods: 1989-1993, 1994-1999), and since 2000, the EU has introduced seven-year programming for the implementation of regional policy - the policy of economic, social and territorial cohesion [14, p. 224-225].

The first models of European regional investment directed resources to significant projects aimed at infrastructure development (such as transport networks and utility services). This, in fact, meant the financing of projects of the European Union, while the implementation of such funding took place virtually within the national boundaries. Regional policy as such did not exist, because there was no systematic full vision of regional problems from the point of view of pan-European vision. This made it necessary to recognize that 
strategies should be inherent by more complex, systematic, comprehensive character in order to promote sustainable economic growth and employment in weak regions. The development of the investigated processes in the $1990 \mathrm{~s}$ was characterized by the development of many programs, increased awareness of the need to overcome the ecological factor, which has been actualized due to economic growth. Among the objectives of regional policy was necessary to establish the responsibility of specifically identified entities for environmental damage caused by them. As a result, the principle of «the one who contaminates - pays» was embodied both legally and enshrined in terms of providing financial support in the framework of European regional programs.

The long-term period of economic restructuring has led to even more disproportionate disparities between the individual groups of the population, which obviously had its negative impact that was expressed, in particular, in social isolation; the destruction of the growth process through unequal access to opportunities. This, in turn, led to qualitative changes in regional politics, which was manifested in adopting laws aimed at overcoming social and economic problems, which simultaneously oriented at involvement of local communities, protecting them and improving their living environment.

S. V. Fedonyuk, V. I. Halias on the basis of territorial differentiation of regions of the European Union classify countries into four groups:

1) «integrated» countries (the Hellenic Republic, the Republic of Ireland, the Portuguese Republic, the Kingdom of Spain). These countries have the poorest regions in the territory of the European Union. Regional policy is characterized by subordination to the tasks of nation-wide economic development;

2) highly developed European countries (the Federal Republic of Germany, the Italian Republic, the French Republic, the United Kingdom of Great Britain and Northern Ireland, etc.). Such countries are characterized by the most significant differences in the level of development of separate regions, with the priority being given to assisting regions to implement structural transformations instead of subsidizing sectors of the economy or enterprises;

3) countries with low population density, remote areas, severe climatic conditions (Republic of Finland, Kingdom of Sweden). Such countries direct their efforts to ensure the balanced development of all regions, while emphasizing the need to overcome the problem of the most remote northern territories;

4) countries with employment problems and structural rearrangement at the municipal level. The regional policy of such countries due to objective factors is not characterized by focus on the elimination of uneven development of regions [15, p. 101]. The region is a socio-territorial model characterized by a certain structure, the elements of which are in close interdependence and interconnection. Violation of one of the elements causes a change in the entire structure [16, p. 33].

For further disclosure of the topic, it would be advisable to refer to the definition of the concept "regional policy». The Law of Ukraine "On the Principles of State Regional Policy» dated 5, 2015 № 156-VIII in Article 1 provides the following definition of the state regional policy: «it is a system 
of goals, measures, means and concerted actions of central and local executive authorities, local self-government bodies and their officials in order to ensure a high level of quality of life for people throughout the territory of Ukraine, taking into account the natural, historical, ecological, economical, geographical, demographic and other features of the regions, their ethnic and cultural identity" [17]. It should be noted that O. S. Morozova, O. V. Morozov emphasize that in the documents of the EU the term "regional policy» has a different meaning. Regional policy of the European Union is a system of measures aimed at strengthening the unity of national economies of the EU member states and ensuring their harmonious development, as well as leveling the differences between regions and eliminating the backwardness of the least developed ones. At the same time, instead of the term "regional policy" is used quite often the term "cohesion policy», which involves simultaneous horizontal proceedings (between regions - regional policy) and vertical (between social strata - social policy), consequently, there is a change in the conceptual apparatus by combining regional and social policies when they are no longer considered separately [18, p. 32].

The rightly statement about regional policy leads T. G. Grosse, considering it as a strategic activity and a government initiative in co-operation with local self-government aimed at developing regions' competitiveness and optimal use of resources for economic growth [19, p. 14].

The regional policy of the EU in the present conditions is carried out in three main directions:

1) assistance to the least-developed regions of the new member states of the European Union - has the objective of economic convergence of such regions to the regions of more developed countries;

2) realization of the system of measures leading to the improvement of competitiveness and employment in the regions;

3) reducing the economic importance of national borders by activation of cooperation between regions and countries.

In the context of the above mentioned, one should agree with the statement of S. I. Tkalenko and V. V. Parkhomenko that regional policy in the European Union is carried out jointly, i.e. with the participation of all member states, and focuses on the transformation of problems into opportunities. It is aimed, first of all, at weakening of socio-economic disparities between regions, reducing the level of backwardness of regions with unfavorable development conditions. At the same time, the regional policy of the EU provides for the separation of countries:

1) with the general underdevelopment (Greek Republic, Portuguese Republic, etc.);

2) regions with underdevelopment, located in the developed countries (for example, Federal Republic of Germany) [20, p. 47].

In order to be effective, regional policy should be aimed at realizing a number of long-term goals. Regional development is a complex process that must be built on effective institutions that require close cooperation between governments, business organizations and social groups at each level. 
In 2010, the so-called Lisbon Strategy was adopted, which established the agrement on the highest priority of the policy of the European Economic Growth and Jobs. The European Union ministers approved this strategy in order to achieve the highest competitiveness and dynamism of the EU economy among all countries around the world. This strategy included a timeline for reviewing and monitoring the strategies of various sectors in order to ensure the further development of the EU towards competitive levels of employment, economic growth, and so on by 2010. However, in 2005 a new emphasis was placed on promoting innovation and job creation. This, in turn, led to the central importance of regional policy, which was reviewed as a means to achieve the goal of improving the competitiveness of the EU. From now on, without diminishing its importance, regional policy was no longer seen as a mechanism to help regions to achieve the European Union's average indicators. EU regional policy has become a policy that defines future opportunities and focuses on them, ensuring engagement of an insufficiently used potential.

Experience has shown that the practical realization of the previous Lisbon strategy in the context of providing employment has not been able to fully achieve the expected result. Significant negative impact on the implementation of these measures was determined by the global financial and economic crisis of 2008-2009 [21, p. 205]. At the same time, one of the key reasons is the inadequate reasonableness of the expected results and their adequacy to economic realities, the deterioration of the economic conjuncture and, consequently, the growth of the level of unemployment [22, p. 212-215]. Therefore, for the successful realization of the current «Europe-2020" [23] strategy as an integral part of the optimization of the employment of the economically active population, all the disadvantages and specifics of the implementation of the previous Lisbon Strategy, the peculiarities of contemporary socio-economic and demographic development and the employment of the EU countries should be taken into account.

The variability of the modern world provides for constant review and modification of the EU's regional policy in order to ensure its expediency. The development of the knowledge economy has taken place, the transfer of greater responsibility for financial control and management for the benefit of the participating countries and regions, the development of the potential of each European region.

Achieving a balance between economic, social and environmental priorities - sustainability - for a long time was recognized as one of the key principles of the policy of regional development of the European Union. Solving ecological problems was carried out in such ways: 1) direct investments in the environmental infrastructure; 2) carrying out of the Strategic Environmental Review [24]; 3) assessment of environmental impact at the stage of preparation of major projects; 4) participation of representatives of environmental groups and agencies in the development and control of programs.

European Regional Policy provides for the implementation of a comprehensive, well-balanced approach to protecting natural resources through the use of alternative energy sources and the development of advanced progressive 
technologies. Innovation within separate programs included the implementation of an environmental audit in order to ensure the neutrality of the final impact of carbon emissions. These processes have been replicated in the Ukrainian legislative reality by the corresponding influence: with the aim of stimulating polluting enterprises to reduce pollution of the environment, as well as approximation to the rates of greenhouse gas emissions in the EU countries, was adopted the relevant Law of Ukraine «On Amendments to the Tax Code of Ukraine and Certain Other Legislative Acts of Ukraine on Improving the Administration and Revision of the Rates of Individual Taxes and Duties" dated November 23, 2018 № 2628-VIII [25].

Within the framework of the realization of European regional policy, the use of regional and local resources and skills is an important element. This means that the sources of innovation become: 1) small companies that comprehensively own information on the local situation; 2) relevant networks that can be involved as a result of broad cooperation.

The Regions for Economic Change Initiative was designed to stimulate local and regional networks in the public and private sectors to share best practices and practices as a way of researching and implementing of changes; improve the ability of interregional and urban networks to test new strategic ideas and their further dynamic integration into regional strategic programs [26].

An extremely important direction is the effective cooperation of the EU member states at all levels: it concerns both political and economic approximation of countries.

The European Union fully recognizes and upholds the principle of diversity and endeavors to implement it, including through the activities of local communities. Very often the administrative-territorial division of a particular country does not allow solving a number of problems effectively. That is why solving of such problems requires appropriate forms of cooperation. In spite of the practical problems of territorial approximation, the territorial diversity of the countries of the European Union is considered as a positive factor.

The rapprochement of EU member states, not least, depends on transport links: the sustainable share of resources is allocated for the realization of transport projects. Thus, regional programs in this area are aimed at attracting investment in the construction and restoration of highways, railways, sea transportation; to create a modern reliable transport system for local residents by public transport in cities.

At the same time, regional development programs are confronted with real problems facing both cities and rural areas, regardless of their geographical location. To solve such problems, a variety of solutions are offered.

As it is mentioned, Europe's towns and cities present a paradox. On the one hand they are the motors of growth in an increasingly global economy, concentrating wealth, knowledge and technical capacity. They are also centers for the provision of public services, such as education, healthcare and transport. At the same time however, many of the worst problems facing society today are concentrated in urban areas, including economic and social exclusion, degradation of the natural and built environment, conges- 
tion, crime, intolerance and racism, and the loss of local identity [27]. The introduction of the URBAN Community Initiative program enabled the development of programs focusing on strong urban partnerships, which led to increased accountability at the local level. Sonia De Gregorio Hurtado mentions: "URBAN integrated in its methodology many of the elements of City Challenge, but assuming a more social approach, as a result of the integration of the British experience and other urban traditions present in the European Context (mainly the urban social tradition of France and the participatory experiences that had been developed in Northern countries). By launching URBAN, the European Commission aimed to introduce innovation in the field of rehabilitation of degraded neighborhoods and to promote the transformation of the governance structures of the planning systems of EU's Member States (Reiter)» [28]. It should be noted that over time, the methodology of sustainable urban development has become the main component of European regional policy.

Unlike cities, rural areas have long encountered in practice with the approach that support for the prospects of local communities and companies could not be guaranteed exclusively by agriculture.

As for the integration of the new member states of the European Union, it is carried out through measures that are generally in line with the EU regional policy: financial solidarity depending on the specific economic situation; formation of effective mechanisms of management of development programs by forming a reliable and transparent administrative system; provision of financing with technical assistance - «JASPERS provides independent advice to the EU countries concerned to enable them to better prepare major infrastructure projects» [29].

The European regional policy is aimed at securing investment in particularly important areas at the regional and local levels, wherein its indisputable positive is the possibility to adapt to changing conditions, flexibility; providing stable and targeted sources of funding, etc. Introducing equal conditions for all economic subjects within the framework of the single market is crucial for the success of the EU economy. The experience of the European Union member states has clearly demonstrated the importance of regional and local knowledge for the sustainable long-lasting development. At the same time, it is impossible to reject the opportunities that manifest themselves in the framework of cross-border and interregional cooperation, through which the possibility of establishing contacts between individual regions across the external borders of the European Union was realized.

The research of regional policy of Ukraine until recently convincingly testified small changes compared with the Soviet times. The need for decentralization of public administration functions, the implementation of socioeconomic programs at the local level, the coordination of national, regional and local interests is directly related to the process of regionalization. Regionalism is important in the current conditions of the transitional stage of post-totalitarian countries, which were for a long time in the most centralized system [30, p. 5]. 
H. O. Shamborovskyi distinguishes such components of the regional policy: 1) economic policy, the essence of which is to provide opportunities for self-development of regions on terms of self-financing and self-sufficiency; 2) social policy, aimed at ensuring an increase in the welfare of the population, equal rights and opportunities for citizens in choosing their place of residence, employment and social protection; 3) scientific and technical policy aimed at identifying priorities for the improvement and development of investment and innovation activities in the region; 4) ecological policy, the main purpose of which is to improve the environment; 5) demographic policy, aimed at inhibiting depopulation processes and destructuring the population; 6) humanitarian policy aimed at the spiritual development of society, its moral and physical condition at the regional level; 7) national policy aimed at ensuring constitutional, political, economic, social and other rights of citizens irrespective of nationality and religion; 8) the foreign economic policy, the main purpose of which is to provide conditions for activation of entrepreneurship, the formation of market infrastructure, attracting foreign investment, increasing the export potential of the region; 9) management policy that concerns the creation of a unified regional governance system that meets the objectives of regional development [31, p. 25].

At present, the process of regionalization is seen as an inalienable part of integration into the European Union. However, deserves an attention the position of Savka O. V., who argues that, in practice, regionalization does not lead to full economic and political integration, but gives regional territorial structures a competitiveness and incentive for higher economic efficiency and an increase in the level of the EU economy as a whole. It should be noted that at the present stage of development regionalism in the European Union is still at a stage of development and in its complete form it is still only a dream. Of course, a regionalist model has best shown itself in federal states, but they do not try to impose their point of view on the internal structure of the state [32, p. 278].

Within the scope of the study of the peculiarities of regional policy, one should dwell separately on the identification of subjects of the investigated phenomenon. According to the Constitution of Ukraine, the most precise list of subjects of regional policy is suggested by S. Bandur and I. Theron. To the primary subjects of the state regional policy they relate Ukrainian society (the main primary subject), social, including regional, groups and strata; secondary entities include the state - central and local government bodies and management (the main secondary subject), local self-government bodies, political parties, non-state unions, associations (trade unions, business associations, etc.) [33, p. 22].

The strategy of the Ukrainian regional policy for the period until 2020 has replaced the strategy of the State development for the period until 2015. The reasons for implementing the new strategy were a number of economic, political and social conditions, among which it is possible to note: 1) a political crisis that radically has changed the placement of productive forces; 2 ) the desire to comply with the strategy of regional development of the European 
Union; 3) the necessity of compliance with European standards in all areas; 4) awareness of the state's need to respond to global trends in development.

In view of the mentioned, the implementation of the Strategy is intended to provide a holistic approach to the formation and implementation of the state regional policy, which involves the combination of such constituent parts:

1) sectoral that focuses on increasing the competitiveness of the regions by optimizing and diversifying the structure of the economy, ensuring efficient specialization of regions with a priority use of their own resource potential;

2) territorial (spatial), which is to achieve equal and balanced development of territories, development of interregional cooperation, prevention of deepening socio-economic disparities by forming «growth points», intensifying the local economic initiative and strengthening the capacity of rural areas, ensuring socio-economic unity and equality of development of regions with the purpose of creating equal conditions for human development;

3) managerial, which focuses on the application of unified approaches to the formation and realization of regional development policy, creation of a unified system of strategic planning and forecasting of the development of the state and regions, optimization of the system of territorial organization of power.

Formation of an effective and transparent mechanism of financial support for regional development requires consideration of the specifics of the development of each region [34].

At the same time, O. Y. Churikanova rightly notes that the regional development strategy of Ukraine is intended to bring the regional policy of the state to European standards, but, given the existing economic and crisis phenomena, the possibility of realization of the strategy is doubtful. Therefore, in terms of today an actual matter is how much Ukraine is able to meet the European regional goals and principles [35, p. 54]. In the context of this, the actual is statement of $\mathrm{O}$. P. Tishchenko regarding the fact that because of a large number of identified goals their priority is lost, "a conflict» between different goals arises, the resources necessary for their achievement are scattered, the activity of management structures is unproductive due to the lack of coordination of their actions. Under these conditions, there is an obvious need for a clear hierarchical structuring of the objectives of regional development, which should be established on the basis of current realities and taking into account changing priorities within the entire world community, and not the use of established production approaches that have been used over the past decades [36, p. 650].

The modernization of regional policy should take place on the basis of domination of the approach, which involves taking into account endogenous regional and local factors of development of territories by ensuring effective local self-government and territorial organization of power [37, p. 33]. The new paradigm of regional policy, which was conceptually, legally and institutionally formed in 2014-2016, involves the transition from an overly centralized model and a sectoral «downstream» approach, which dominated so far, to a balanced multilevel regional development management system. It involves the 
identification and activation of still untapped development potential (within the macroregions, regions and micro-regions) through integrated development projects, which are planned both «from the top down», and «from the bottom up", as well as state investments in tangible and intangible assets in the form of "physical» and «soft» infrastructure projects. The main focus of change is to use insufficiently realized potential in all regions by maximizing engagement to work together all important subjects of regional development [38].

Since 2015, Ukraine has created four powerful financial instruments for the consolidation of the state space: 1) income alignment; 2) financing of regional development based on its formula; 3) subvention for the development of the infrastructure of the united territorial communities; 4 ) increasing the number of local budgets that went into direct relations with the state budget. The united territorial communities, which were formed from the village councils not sufficiently integrated with each other, got the same problem of their own cohesiveness as Ukraine, $i$ and now, at the local level, they have to take steps to create their new, cohesive community, a new local identity, which also reduces the influence of the regional political elite.

Most of the strategic plans of the united territorial community include such a priority as community integration [39]. It is also important that when developing the regional policy of the state, it is necessary to reconcile the state interests with the interests of all administrative-territorial units of the regional level. Hence, the complexity is associated with the fact that when forming this policy it is necessary to take into account the relations between the subjects of the state regional policy both among themselves and with the subjects of the policy of the regions [40, p. 261].

Conclusions. Today it is hardly possible to state with certainty that the regional policy of the European Union has achieved all the intended purposes, and even more so, in pre-established terms. However, the presence of a significant amount of problems faced by the EU in the implementation of regional policy does not give grounds for claiming that it is ineffective - on the contrary, the integrated approach applied by the EU demonstrates positive dynamics, in particular, for the development of the poorest regions.

For now, Ukraine is not a member state of the European Union, though the constitutional recognition of the irreversibility of the European course of Ukraine [41] gives all the grounds, both in the legal field and in the statebuilding reality, to affirm that orientation on positive European experience and taking into account shortcomings, with which the EU member states have already encountered in the implementation of regional policy, is not only extremely relevant but vital for the Ukrainian state at the present stage of constitutional reforms. In terms of the present it is impossible to form mechanisms of state regional policy, not taking into account the current trends that are used by the international community.

Perhaps the most important requirement of an effective regional policy is a focus on results, which is achieved, in particular, by a qualitative increase in the efficiency of management. For Ukraine, this means, first of all, the fruitful completion of the decentralization reform, reducing bureaucratic pro- 
cedures, setting up productive interaction between state bodies and local selfgovernment bodies at different levels.

Since 2014, regional policy in Ukraine has begun to acquire the characteristics of the European Union's regional policy. The current legislation regulates the fullest extent of public relations in the sphere of regional policy during the time of independence of Ukraine and generally conforms to the established European standards. Y In this regard, the state regional policy faces complex challenges associated with the need to provide each region with all the possibilities to fully use its internal potential while maintaining national interests. The modern stage of state formation is characterized by the implementation of systemic influence on the improvement of regional policy And although the proportion of problems (disproportion of regional development, dynamic transformation processes in the economic development of the country, etc.) still needs to be solved, the correctness and performance of the course chosen by the Ukrainian state is already demonstrated today.

\section{References}

1. Kabinet Ministriv Ukrainy: Reforma detsentralizatsii. Accessed June 1, 2019. https://www. kmu.gov.ua/ua/diyalnist/reformi/efektivnevryaduvannya/reforma -decentralizaciyi.

2. Prokopenko, O. Y. Stratehichne planuvannia mistsevoho ekonomichnoho rozvytku na rivni silskykh hromad : avtoref. dys. ... kand. ekonom. nauk. Poltava, 2007.

3. Topalova, E. Kh. Nablyzhennia vitchyznianoi systemy vriaduvannia do yevropeiskykh standartiv: rehionalnyi riven : avtoref. dys... kand. nauk z derzh. upravl. Odesa, 2008.

4. Kolyshko, R. A. Detsentralizatsiia publichnoi vlady v unitarnii derzhavi : avtoref. dys. ... kand. yuryd. nauk. Kyiv, 2003. Accessed June 1, 2019. http://www.irbisnbuv.gov.ua/cgibin/irbis_nbuv/cgiirbis_64.exe?C21COM=2\&I21DBN=ARD\&P21DBN=ARD\&Z21ID=\&IMA GE_FILE_DOWNLOAD=1\&Image_file_name=DOC $/ 2003 / 03 \mathrm{kravud} . z i p$

5. Kuryliak, M. Y. «Evoliutsiia kontseptsii «Ievropy rehioniv» u ramkakh rehionalnoi polityky.» Ekonomichnyi visnyk Donbasu. 2(52) (2018): 60-67.

6. Bila, S. O. «Vplyv detsentralizatsii na stymuliuvannia ekonomichnoho zrostannia terytorialnykh hromad v Ukraini." Naukovyi chasopys NPU imeni M. P. Drahomanova. Seriia 18 : Ekonomika i pravo. 27 (2015): 60-68.

7. Shtefan, V. S. «Dosvid zarubizhnykh krain - chleniv Yevropeiskoho Soiuzu v reformuvanni administratyvno-terytorialnoho ustroiu." Problemy zakonnosti. 125 (2014): 184-192.

8. Sieriebriak, K. I. Rozvytok informatsiinoi infrastruktury ekonomichnoho spivrobitnytstva rehioniv : avtoref. dys... d-ra ekonom. nauk. Sievierodonetsk, 2018.

9. Melnyk A., Adamyk, V. «Rehionalna polityka YeS ta Ukrainy v umovakh pohlyblennia superechnostei hlobalizatsii.» Zhurnal yevropeiskoi ekonomiky. 12 (1) (2013): 57-78.

10. Polikarpova, O. «Rehionalna polityka YeS: praktychnyi dosvid dlia Ukrainy.»Visnyk Ternopilskoho natsionalnoho ekonomichnoho universytetu. 3 (2015): 101-110.

11. Krasnopolska, T. M. «Rehionalna polityka YeS: mozhlyvosti vykorystannia dosvidu dlia Ukrainy.» Politychne zhyttia. 4 (2016): 81-86.

12. Treaty establishing the European Community (Nice consolidated version). Accessed June 1, 2019. https://eur-lex.europa.eu/legal-content/EN/TXT/?uri=CELEX \%3A12002E \% 2 FTXT.

13. Hranberh, A. H. Osnovi rehyonalnoi ekonomyky : uchebnyk dlia vuzov. M : HU VShE, 2001.

14. Vdovichen, A. A., Kruhlianko, A. V. «Dysproportsiinist rozvytku rehioniv: yevropeiskyi dosvid ta yoho zastosuvannia v Ukraini.» Aktualni problemy ekonomiky. 1 (163) (2015): 220231.

15. Ievropeiska intehratsiia: rehionalna polityka Yevropeiskoho Soiuzu. Korotkyi leksykon : posibnyk / Volynskyi derzh. un-t im. Lesi Ukrainky. Fakultet mizhnarodnykh vidnosyn; uklad. S. V. Fedoniuk, V. I. Halias. Lutsk : Vezha, 2007. 
16. Pysarenko, S. M. «Suspilno-terytorialni systemy v teoretychnykh kontseptsiiakh rehionalizmu.» Sotsialno-ekonomichni doslidzhennia $v$ perekhidnyi period. Rehionalni suspilni syste$m y .3(1)$ (2004): 31-38.

17. Pro zasady derzhavnoi rehionalnoi polityky : Zakon Ukrainy vid 05.02.2015 r. № 156VIII. Accessed June 1, 2019. https://zakon.rada.gov.ua/laws/show/156-19

18. Morozova, O. S., Morozov, O. V «Rehionalna polityka v konteksti yevrointehratsii.» Biznesnavihator. 4 (1) (2017): 31-34.

19. Grosse, T. G. Cele i zasady polityki regionalnej panstwa. Instytut Spraw Publicznych, 2009. 48 s. Accessed June 1, 2019. http://docplayer.pl/39780888-Cele-i-zasady-polityki-regionalnej-panstwa.html

20. Tkalenko, S. I., Parkhomenko, V. V. "Yevropeiska rehionalna polityka: osnovni zasady rehuliuvannia.» Naukovyi visnyk Natsionalnoi akademii statystyky, obliku ta audytu. 2 (2015): 46-52.

21. Nartiuk, O. V. «Stratehiia «Ievropa 2020» yak skladova mekhanizmu optymizatsii zainiatosti naselennia v karinakh YeS.» Sotsialno-trudovi vidnosyny: teoriia ta praktyka. 2 (2015): 201-207.

22. Economic Outlook. World Economic Outlook. 81 (2007): 212-215.

23. A European strategy for smart, sustainable and inclusive growth. Europe 2020. Accessed June 1, 2019. http://ec.europa.eu/eu2020/pdf/COMPLET \%20EN \% 20BARROSO $\% 20 \% 20 \% 20007 \% 20 \% 20$ Europe $\% 202020 \% 20 \% 20 \mathrm{EN} \% 20$ version.pdf

24. Strategic Environmental Assessment - SEA. Accessed June 1, 2019. http://ec.europa.eu/ environment/eia/sea-legalcontext.htm

25. Pro vnesennia zmin do Podatkovoho kodeksu Ukrainy ta deiakykh inshykh zakonodavchykh aktiv Ukrainy shchodo pokrashchennia administruvannia ta perehliadu stavok okremykh podatkiv i zboriv : Zakon Ukrainy vid 23.11.2018 r. № 2628-VIII. Accessed June 1, 2019. https://zakon.rada.gov.ua/laws/show/2628-19

26. Regions for Ecomonic Change. Accessed June 1, 2019. https://ec.europa.eu/regional_policy/ sources/docgener/presenta/demo/demochallenge_en.pdf

27. Partnership with the Cities. The URBAN Community Initiative. Accessed June 1, 2019. https:// ec.europa.eu/regional_policy/sources/docgener/presenta/cities/cities_en.pdf

28. Hurtado, Sonia De Gregorio . «The Implementation of the URBAN Community Initiative: A Transformative Driver towards Collaborative Urban Regeneration? Answers from Spain.» European Journal of American Studies. 10(3) (2015). Accessed June 1, 2019. https://journals. openedition.org/ejas/113

29. JASPERS: Joint Assistance to Support Projects in European Regions. Accessed June 1, 2019. https://ec.europa.eu/regional_policy/archive/thefunds/instruments/ jaspers_en.cfm

30. Oluiko, V. «Derzhavna rehionalna polityka: formuvannia i realizatsiia.»Visnyk Khmelnytskoho instytutu rehionalnoho upravlinnia i prava. 1 (2002): 5-8.

31. Shamborovskyi H. O. Rehionalna polityka Yevropeiskoho Soiuzu : navchalnyi posibnyk. K. : Znannia, 2011.

32. Savka, O. V. «Rehionalna polityka Polshchi - uroky dlia Ukrainy.»Visnyk Mariupolskoho derzhavnoho universytetu. Seriia: Istoriia. Politolohiia. 12 (2015): 277-283.

33. Holikov, A. P., Prav, Yu. H. «Suchasnyi stan ta perspektyvy rehionalnoi polityky v Ukraini.» V Formuvannia mekhanizmu rehionalnoho upravlinnia $v$ Ukraini : materialy naukovo-praktychnoi konfenetsii. Kharkiv, Lystopada 29, 2001. Kharkiv : Vyd-vo KharRI UADU «Mahistr», 2002. S. 22-24.

34. Derzhavna stratehiia rehionalnoho rozvytku : zatverdzhena postanovoiu Kabinetu Ministriv Ukrainy vid 06.08.2014 r. № 385. Accessed June 1, 2019. https://zakon.rada.gov.ua /laws/ show/385-2014- \% D0 \% BF

35. Churikanova, O. Yu. «Rehionalna polityka Ukrainy, problemy ta perspektyvy v konteksti rehionalnoi polityky.» Ekonomika ta derzhava. 2 (2015): 51-54.

36. Tyshchenko, O. P. «Shliakhy udoskonalennia mekhanizmu realizatsii derzhavnoi rehionalnoi polityky v Ukraini.» Formuvannia rynkovoi ekonomiky. 21 (2009): 649-653.

37. Shults, S. L. «Rehionalna polityka v Ukraini: evoliutsiini zasady ta stratehichni perspektyvy.» Rehionalna ekonomika. 2 (2014): 26-36.

38. Hrupa radnykiv provela dlia pratsivnykiv Dyrektoratu rehionalnoho rozvytku Minrehionu seminar «Rehionalna polityka v YeS - uroky dlia Ukrainy». Accessed June 1, 2019. http:// rdpa.regionet.org.ua/events/190 
39. Rehionalna polityka: dva roky shliakhu — tezy Anatoliia Tkachuka. Accessed June 1, 2019. https://decentralization.gov.ua/news/3863

40. Holubiak, N. R. «Naukove osmyslennia katehorii «rehionalna polityka». Panorama politolohichnykh studii. 11 (2013): 254-262.

41. Konstytutsiia Ukrainy : Zakon Ukrainy vid 28.06.1996 r. № 254k/96-VR. Accessed June 1, 2019. http://zakon5.rada.gov.ua/laws/show/254k/96-vr

\section{Список використаної літератури}

1. Кабінет Міністрів України: Реформа децентралізації. URL: https://www.kmu.gov.ua/ ua/diyalnist/reformi/efektivnevryaduvannya/reforma-decentralizaciyi (дата звернення: 01.06.2019).

2. Прокопенко О. Ю. Стратегічне планування місцевого економічного розвитку на рівні сільських громад : автореф. дис. ... канд. економ. наук. Полтава, 2007. 20 с.

3. Топалова Е. Х. Наближення вітчизняної системи врядування до європейських стандартів: регіональний рівень : автореф. дис. ... канд. наук з держ. управл. Одеса, 2008. 20 с.

4. Колишко Р. А. Децентралізація публічної влади в унітарній державі : автореф. дис. ... канд. юрид. наук. Київ, 2003. 16 с. URL: http://www.irbisnbuv.gov.ua/cgibin/irbis nbuv/ cgiirbis_64.exe?C21COM=2\&I21DBN=ARD\&P21DBN=ARD\&Z21ID=\&IMAGE_FILE_ DOWNLOAD=1\&Image_file_name=DOC/2003/03kravud.zip (дата звернення:: 01.06.2019).

5. Куриляк М. Ю. Еволюція концепції «Європи регіонів» у рамках регіональної політики ЄC. Еконолічний вісник Донбасу. 2018. № 2 (52). С. 60-67.

6. Біла С. О. Вплив децентралізації на стимулювання економічного зростання територіальних громад в Україні. Науковий часопис НПУ імені М. П. Драгоманова. Серія 18: Економіка і право. 2015. Вип. 27. С. 60-68.

7. Штефан В. С. Досвід зарубіжних країн - членів Європейського Союзу в реформуванні адміністративно-територіального устрою. Проблели законності. 2014. Вип. 125. С. 184-192.

8. Серєбряк К. І. Розвиток інформаційної інфраструктури економічного співробітництва регіонів : автореф. дис. ... д-ра економ. наук. Сєвєродонецьк, 2018. 34 с.

9. Мельник А., Адамик В. Регіональна політика ЄС та України в умовах поглиблення суперечностей глобалізації. Журнал європейської еконоліки. 2013. Т. 12, № 1. С. 57-78.

10. Полікарпова О. Регіональна політика ЄС: практичний досвід для України. Вісник Тернопільського національного економічного університету. 2015. Вип. 3. С. 101-110.

11. Краснопольська Т. М. Регіональна політика ЄС: можливості використання досвіду для України. Політичне життя. 2016. № 4. С. 81-86.

12. Treaty establishing the European Community (Nice consolidated version). URL: https://eurlex.europa.eu/legal-content/EN/TXT/?uri=CELEX \% 3A 12002E \% 2 FTXT (дата звернення: 01.06.2019).

13. Гранберг А. Г. Основы региональной экономики : учебник для вузов. М : ГУ ВШЭ, 2001. $495 \mathrm{c}$.

14. Вдовічен А. А., Круглянко А. В. Диспропорційність розвитку регіонів: європейський досвід та його застосування в Україні. Актуальні проблеми економіки. 2015. № 1 (163). С. $220-231$.

15. Європейська інтеграція: регіональна політика Європейського Союзу. Короткий лексикон : посібник / Волинський держ. ун-т ім. Лесі Українки. Факультет міжнародних відносин; уклад. С. В. Федонюк, В. І. Галяс. Луцьк : Вежа, 2007. 110 с.

16. Писаренко С. М. Суспільно-територіальні системи в теоретичних концепціях регіоналізму. Соціально-еконолічні дослідження в перехідний період. Регіональні суспільні системи. 2004. Вип. 3, ч. 1. С. 31-38.

17. Про засади державної регіональної політики : Закон України від 05.02.2015 р. № 156VIII. URL: https://zakon.rada.gov.ua/laws/show/156-19 (дата звернення: 01.06.2019).

18. Морозова О. С., Морозов О. В Регіональна політика в контексті євроінтеграції. Бізнес-навігатор. 2017. Вип. 4. С. 31-34.

19. Grosse T. G. Cele i zasady polityki regionalnej państwa. Instytut Spraw Publicznych, 2009. 48 c. URL: http://docplayer.pl/39780888-Cele-i-zasady-polityki-regionalnej-panstwa.html (дата звернення: 01.06.2019). 
20. Ткаленко С. І., Пархоменко В. В. Свропейська регіональна політика: основні засади регулювання. Науковий вісник Національної акаделії статистики, обліку та аудиту. 2015. № 2. C. $46-52$.

21. Нартюк О. В. Стратегія «Європа 2020» як складова механізму оптимізації зайнятості населення в країнах ЄС. Соціально-трудові відносини: теорія та практика. 2015. № 2. C. 201-207.

22. Economic Outlook. World Economic Outlook. 2007. № 81. P. 212-215.

23. A European strategy for smart, sustainable and inclusive growth. Europe 2020. URL: http:// ec.europa.eu/eu2020/pdf/COMPLET \% 20EN \% 20BARROSO \% $20 \% 20 \% 20007 \% 20$ - $\% 20$ Europe \% $202020 \% 20$ - \% 20EN \% 20version.pdf (дата звернення: 01.06.2019).

24. Strategic Environmental Assessment - SEA. URL: http://ec.europa.eu/ environment/eia/ sea-legalcontext.htm (дата звернення: 01.06.2019).

25. Про внесення змін до Податкового кодексу України та деяких інших законодавчих актів України щодо покращення адміністрування та перегляду ставок окремих податків $\mathrm{i}$ зборів : Закон України від 23.11.2018 р. № 2628-VIII. URL: https://zakon.rada.gov.ua/ laws/show/2628-19 (дата звернення: 01.06.2019).

26. Regions for Ecomonic Change. URL: https://ec.europa.eu/regional_ policy/sources/docgener/presenta/demo/demochallenge_en.pdf (дата звернення: 01.06.2019).

27. Partnership with the Cities. The URBAN Community Initiative. URL: https://ec.europa.eu/regional_policy/sources/docgener/presenta/cities/cities_en.pdf (дата звернення: 01.06.2019).

28. Hurtado Sonia De Gregorio. The Implementation of the URBAN Community Initiative: A Transformative Driver towards Collaborative Urban Regeneration? Answers from Spain. European Journal of American Studies. 2015. № 10. URL: https://journals.openedition.org/ ејаs/11354 (дата звернення: 01.06.2019).

29. JASPERS: Joint Assistance to Support Projects in European Regions. URL: https:// ec.europa.eu/regional_policy/archive/thefunds/instruments/jaspers_en.cfm (дата звернення: 01.06.2019).

30. Олуйко В. Державна регіональна політика: формування і реалізація. Вісник Хмельницького інституту регіонального управління і права. 2002. № 1. С. 5-8.

31. Шамборовський Г. О. Регіональна політика Європейського Союзу : навчальний посібник. К. : Знання, 2011. 187 с.

32. Савка О. В. Регіональна політика Польщі - уроки для України. Вісник Маріупольського державного університету. Серія: Історія. Політологія. 2015. Вип. 12. С. 277-283.

33. Голіков А. П., Прав Ю. Г. Сучасний стан та перспективи регіональної політики в Україні. Формування механізму регіонального управління в Украӥні : матеріали науково-практичної конфенеції (Харків, 29 листопада 2001 р.). Харків : Вид-во ХарРІ УАДУ «Магістр», 2002. C. 22-24.

34. Державна стратегія регіонального розвитку : затверджена постановою Кабінету Міністрів України від 06.08.2014 р. № 385. URL: https://zakon.rada.gov.ua/laws/show/3852014- \% D0 \% BF (дата звернення: 01.06.2019).

35. Чуріканова О. Ю. Регіональна політика України, проблеми та перспективи в контексті регіональної політики ЄС. Еконоліка та держава. 2015. № 2. С. 51-54.

36. Тищенко О. П. Шляхи удосконалення механізму реалізації державної регіональної політики в Україні. Формування ринкової еконоліки. 2009. № 21. С. 649-653.

37. Шульц С. Л. Регіональна політика в Україні: еволюційні засади та стратегічні перспективи. Регіональна економіка. 2014. № 3. С. 26-36.

38. Група радників провела для працівників Директорату регіонального розвитку Мінрегіону семінар «Регіональна політика в $\mathrm{CC}$ - уроки для України». URL: http://rdpa.regionet. org.ua/events/190 (дата звернення: 01.06.2019).

39. Регіональна політика: два роки шляху - тези Анатолія Ткачука. URL: https:// decentralization.gov.ua/news/3863 (дата звернення: 01.06.2019).

40. Голуб'як Н. Р. Наукове осмислення категорії «регіональна політика». Панорама політологічних студій. 2013. Вип. 11. С. 254-262.

41. Конституція України : Закон України від 28.06.1996 p. № 254к/96-BP. URL: http:// zakon5.rada.gov.ua/laws/show/254к/96-вр (дата звернення: 01.06.2019).

Стаття надійшла до редакцї̈ 01.06.2019 
Віткова В. С.

кафедра конституційного права

Національний університет «Одеська юридична академія»

Фонтанська дорога, 23, Одеса, 65009, Україна

\section{ЄВРОПЕЙСЬКА РЕГІОНАЛЬНА ПОЛІТИКА: ЗАГАЛЬНА ХАРАКТЕРИСТИКА, ВИКЛИКИ ТА ПЕРСПЕКТИВИ ДЛЯ УКРАЇНИ}

\section{Резюме}

Робота присвячена дослідженню характеристик європейської регіональної політики. Регіональна політика ЄC формує базис для політичного діалогу з іншими країнами світу, які стикаються із необхідністю розв'язання схожих за правовою природою проблем. Необхідність наближення вітчизняної системи публічної влади і державного управління до європейських стандартів, розбудови ефективної моделі регіонального врядування зумовлює необхідність поглибленого дослідження європейської регіональної політики.

На сьогодні Україна не є країною-учасницею Європейського Союзу, хоча конституційне закріплення європейського курсу України дає всі підстави стверджувати, що орієнтація на європейський досвід та врахування недоліків, які вже поставали перед країнами-членами ЄС, є надзвичайно актуальною для Української держави. Чи не найважливішою вимогою дієвої регіональної політики виступає спрямованість на результат, що досягається зокрема якісним підвищенням ефективності управління. Для України це означає, в першу чергу, результативне завершення реформи децентралізації, скорочення бюрократичних процедур, налаштування продуктивної взаємодії між державними органами та органами місцевого самоврядування на різних рівнях.

32014 року регіональна політика в Україні почала набувати характерних рис регіональної політики Свропейського Союзу. Сформоване законодавство регулює максимально повний за часи незалежності України об’єм суспільних відносин у сфері регіональної політики та відповідає європейським стандартам. У зв'язку із цим перед державною регіональною політикою постають завдання, пов'язані із необхідністю надання кожному регіону всієї повноти можливостей задля максимального використання свого внутрішнього потенціалу за умови збереження загальнодержавних інтересів. Сучасний етап державотворення характеризується здійсненням системного впливу на вдосконалення регіональної політики. I хоча питома вага проблем (диспропорційність розвитку регіонів, динамічність трансформаційних процесів в економічному розвитку країни та ін.) ще потребують свого вирішення, правильність і продуктивність обраного Українською державою курсу демонструється вже сьогодні.

Ключові слова: європейська регіональна політика, Свропейський Союз, регіони, розвиток регіонів, управління на регіональному рівні. 
Виткова В. С.

кафедра конституционного права

Национальный университет «Одесская юридическая академия»

Фонтанская дорога, 23, Одесса, 65009, Украина

\section{ЕВРОПЕЙСКАЯ РЕГИОНАЛЬНАЯ ПОЛИТИКА: ОБЩАЯ ХАРАКТЕРИСТИКА, ВЫЗОВЫ И ПЕРСПЕКТИВЫ ДЛЯ УКРАИНЫ}

\section{Резюме}

Работа посвящена исследованию основных характеристик европейской региональной политики. Региональная политика ЕС является квинтэссенцией опыта для стран мира, сталкивающихся с необходимостью решения схожих по правовой природе проблем. Необходимость приближения отечественной системы публичной власти и государственного управления к европейским стандартам, развития эффективной модели регионального управления и т. п. вызывает необходимость углубленного исследования европейской региональной политики.

Сегодня Украина не является страной-участницей Европейского Союза, хотя конституционное закрепление европейского курса Украины дает все основания утверждать, что ориентация на положительный европейский опыт и учет недостатков, с которыми уже сталкивались страны-участники ЕС при внедрении региональной политики, является не только чрезвычайно актуальной, но и жизненно необходимой для Украинского государства на современном этапе конституционных преобразований. В современных условиях невозможно формировать механизмы государственной региональной политики, не учитывая современные тенденции, которые использует международное сообщество.

C 2014 года региональная политика в Украине начала приобретать черты региональной политики Европейского Союза. Сложившееся законодательство регулирует максимально полный за время независимости Украины объем общественных отношений в сфере региональной политики и соответствует европейским стандартам. Перед государственной региональной политикой возникают сложные задачи, связанные с необходимостью предоставления каждому региону всей полноты возможностей для максимального использования своего внутреннего потенциала при сохранении общегосударственных интересов. Современный этап государства характеризуется осуществлением системного воздействия на совершенствование региональной политики. И хотя множество проблем (диспропорция развития регионов, динамичность трансформационных процессов в экономическом развитии страны и др.) все еще требуют своего решения, правильность и производительность избранного Украинским государством курса демонстрируется уже сегодня.

Ключевые слова: европейская региональная политика, Европейский Союз, регионы, развитие регионов, управление на региональном уровне. 